\title{
Analisis Usaha Keripik Keladi Di Kabupaten Mamasa
}

\author{
Takril $^{1}$, Metusalak ${ }^{2}$ \\ ${ }^{1}$ Program Studi Agribisnis Universitas Al Asyariah Mandar \\ Email : takril_unasman82@yahoo.co.id \\ metusalak@gmail.com
}

\begin{abstract}
Abstrak
Penelitian ini dilaksanakan di Mamasa, yang berlangsung 3 bulan yang dimulai pada bulan Februari sampai dengan April 2015. Penelitian ini bertujuan untuk mengetahui pendapatan dan tingkat kelayakan usaha pembuatan keripik keladi Di Desa Makuang, Kecamatan Messawa, Kabupaten Mamasa. Metode analisis data yang digunakan dalam penelitian ini adalah metode analisis kuantitatif yaitu untuk menentukan pendapatan dan tingkat kelayakan usaha pembuatan keripik keladi Di Desa Makuang, Kecamatan Messawa, Kabupaten Mamasa. Hasil penelitian menunjukkan pendapatan bersih yang diperoleh usaha pembuatan keripik keladi Di Desa Makuang, Kecamatan Messawa, Kabupaten Mamasa dalam melakukan usahanya sebesar Rp 126.938 dan R/C ratio yang diperoleh sebesar 1,009 berarti usaha tersebut dinyatakan layak, karena setiap penambahan biaya $\mathrm{Rp} 1,-$ maka akan memperoleh keuntungan sebesar $\mathrm{Rp}$ 1,009, ,- Dengan demikian usaha pembuatan keripik keladi Di Desa Makuang, Kecamatan Messawa, Kabupaten Mamasa dinyatakan layak.
\end{abstract}

Keywords: Pendapatan, Usaha, Keripik Keladi

\section{Pendahuluan}

Sektor pertanian mempunyai peranan yang sangat besar dalam pertumbuhan ekonomi negara terutama negara yang bercorak agraris seperti Indonesia. Pembangunan ekonomi menitikberatkan pada bidang pertanian dan industri yang berbasis pertanian atau biasa disebut agroindustri. Dalam system agribisnis, agroindustri adalah salah satu subsistem yang bersamasama subsistem lain membentuk agribisnis.

Sistem agribisnis terdiri dari subsistem input (agroindustri hulu), usahatani (pertanian), sistem output (agroindustry hilir), pemasaran dan penunjang. Dengan demikian pembangunan agroindustri tidak dapat dilepaskan dari pembangunan agribisnis secara keseluruhan. Pembangunan agroindustri akan dapat meningkatkan produksi, harga hasil pertanian, pendapatan petani, serta mengahasilkan nilai tambah hasil pertanian (Masyhuri,1994).

Sektor pertanian dalam wawasan agribisnis dengan perannya dalam perekonomian nasional memberikan beberapa hal yang menunjukkan keunggulan yang dapat dipertimbangkan. Keunggulan tersebut antara lain nilai tambah pada agroindustri, misalnya dengan cara pengawetan produk pertanian menjadi produk olahan yang lebih tahan lama dan siap untuk dikonsumsi. Mengingat sifat produk pertanian yang tidak tahan lama maka peran agroindustri sangat diperlukan.keladi merupakan salah satu tanaman pangan yang memiliki banyak kelebihan salah satunya sebagai bahan olahan kerupuk Usaha kecil merupakan salah satu penyangga dalam kegiatan ekonomi masyarakat. Namun demikian dalam proses usaha industri kecil banyak menghadapi berbagai masalah khususnya dalam hal modal. Faktor produksi tersebut merupakan instrument yang penting dalam pertumbuhan dan pengembangan usaha.Pengembangan usaha kecil menghadapi berbagai kendala seperti tingkat kemampuan, keterampilan, keahlian, manajemen sumberdaya manusia sampai ke pemasaran yang mengakibatkan pengusaha kecil tidak mampu menjalangkan usahanya dengan baik. Tujuan pengolahan keladi itu sendiri adalah untuk meningkatkan keawetan tanaman keladi itu sehingga layak dikonsumsi dan memanfaatkan umbi keladi agar memperoleh nilai jual yang tinggi dipasaran.Salah satu industri yang saat ini sedang dikembangkan di Kecamatan Messawa adalah industri pengolahan Keladi sebagai bahan baku pembuatan keripik keladi, yaitu usaha yang dikelola oleh home industri pembuatan kerupuk skala rumah tangga di Kecamatan Messawa.

Berdasarkan survey awal diketahui bahwa pembuatan keripik keladi di lokasi penelitian masih menggunakan cara tradisional dalam pemanfaatan setiap tahapan proses, namun harga jual sangat baik dipasaran bahkan pembeli/ konsumen dari berbagai daerah salah satunya adalah konsumen dari luar daerah.

Ketatnya persaingan di pasar makanan tidak menyurutkan langkah bagi pembuatan keripik dalam skala home rumah tangga untuk mencoba memperoduksi suatu makanan tradisional yang tidak kalah menarik dengan makanan instan. Tentunya dengan harapan mampu bersaing dalam pasar makanan.Produk tersebut adalah keripik keladi.

Jenis usaha yang akan dijalankan home industri pembuatan kerupuk keladi skala rumah tangga di 
Kecamatan Messawa ini memodifikasi dari segi bentuk maupun rasa sehingga mampu menghasilkan makanan yang berkualitas dan menarik.

Sehubungan dengan hal tersebut di atas, maka penulis mencoba melakukan penelitian dengan judul "Analisis Pendapatan Usaha Keripik Keladi Di Desa Makuang, Kecamatan Messawa, Kabupaten Mamasa “

\section{Metodologi}

Penelitian ini dilaksanakan Di Desa Makuang, Kecamatan Messawa, Kabupaten Mamasa, yang berlangsung 3 bulan yang dimulai pada bulan Februari sampai dengan April 2015.

Metode penelitian yang digunakan dalam penelitian ini adalah kuantitatif dengan pendekatan proposive sampling (sengaja) dengan alasan sampel yang digunakan sudah pasti yaitu pemilik usaha pembuatan usaha keripik keladi dan karyawannya.

Untuk mengetahui apakah tersebut memperoleh keuntungan atau kerugian maka model analisis yang akan digunakan dalam penelitian ini sebagai berikut :

\section{Analisis Pendapatan}

Soekartawi (1995) menyatakan untuk mengetahui besaranya pendapatan petani responden digunakan analisis pendapatanyang diformulasikan sebagai berikut :

$$
\begin{aligned}
& \pi \quad=\mathrm{TR}-\mathrm{TC} \\
& \text { Keterangan : } \\
& \pi=\text { Pendapatan (income); } \\
& \mathrm{TR}=\text { Total penerimaan (total revenue) } \\
& \mathrm{TC}=\text { Total biaya (total cost). }
\end{aligned}
$$

Analisis Revenue Cost Ratio (R/C Ratio);

Analisis R/C Ratio adalah salah satu parameter kelayakan usaha yang digunakan untuk melihat atau mengetahui apakah usaha tersebut memberikan keuntungan atau kerugian. perhitungan $\mathrm{R} / \mathrm{C}$ adalah sebagai berikut :

\section{$\mathrm{R} / \mathrm{C}=$ Total Penerimaan}

Total Biaya Produksi

Kreteria kelayakan usaha adalah :

$\mathrm{R} / \mathrm{C}>1$ berarti layak

$\mathrm{R} / \mathrm{C}<1$ berarti tidak layak (rugi)

$\mathrm{R} / \mathrm{C}=1$ berarti impas

\section{Analisis Break Event Point (BEP)}

BEP merupakan analisis yang digunakan untuk mengetahui batas nilai produksi mencapai titik impas, dinyatakan impas apabila nilai BEP $>1$ dengan rumus sebagai berikut :

BEP produksi $=$ Total biaya/ Harga penjualan

BEP Harga = Total Biaya $/$ Total Produksi

\section{Hasil Dan Pembahasan}

\section{Gambaran Umum Usaha Pembuatan Keripik Keladi}

(a) Sejarah Singkat

Usaha pembuatan kripik keladi pertama kali dididrikan pada tanggal 20 Mei 2013 oleh Bapak Ilhamyang terletak di Desa Makuang Kecamatan Messawa. Bidang usaha yang digeluti oleh Bapak
Herman adalah usaha pembuatan kripik keladi.Usaha pembuatan keripik keladi merupakan usaha skala kecil industri rumah tangga dengan memanfaatkan bahan baku di sekitar Kecamatan Messawa.

Usaha tersebut akhirnya mulai dijalankan dengan modal awal oleh Bapak Ilham atau bisa dikatakan modal pribadi. Sehingga usaha ini tidak bisa dilakukan secara langsung tetapi secara bertahap yang dikarenakan keterbatasan modal.Modal awal Bapak Ilham dalam memulai usahnya sebesar Rp 6.000.000. Setelah modal terkumpul dan segala kebutuhan terpenuhi maka kegiatan usaha ini sudah mulai berjalan.

Awal usaha tersebut belum begitu mendapatkan laba atau keuntungan yang besar karena masih banyak peralatan yang harus ditambahkan atau dilengkapi guna mengembangkan usaha pembuatan kripik keladi.Bahkan pada tahap awal tersebut banyak kendala yang dihadapi antara lain masalah pemasaran, sarana dan prasarana yang belum terpenuhi serta keterampilan dalam menjalangkan usaha tersebut. Namun kendati demikian tidak mengalami kerugian walaupun usaha tidak berjalan secara efektif dan maksimal setidaknya usaha tersebut memperoleh keuntungan peralatan, sehingga memudahkan pelaksanaan kegiatan usaha selanjutnya.

(b) Tujuan Usaha

Tujuan umum yaitu memperkenalkan dan mempertahankan kualitas produk makanan lokal "Kripik Keladi” yang mampu menjadi makanan yang berkualitas, menarik dan diterima oleh kalangan masyarakat sebagai makanan cepat saji atau cemilan.Tujuan khusus yaitu untuk memperoleh hasil target kripik keladi dan juga membuka lapangan pekerjaan bagi masyarakat setempat khususnya di Desa Makuang.

\section{Sumberdaya Usaha}

(a) Sumberdaya Manusia

Sumberdaya manusia merupakan faktor yang sangat esensial dalam kelangsungan kegiatan suatu usaha karena menusialah yang memeiliki ide dan strategi yang menjalangkan usaha untuk memproduksi suatu jenis produk, serta mampu melakukan persaingan di dalam kegiatan pengembangan usaha itu sendiri.

Adapun sumberdaya manusia yang dimiliki oleh usaha pembuatan kripik keladi dalam menjalangkan usahanya dapat dilihat pada lampiran 2 .

(b) Sumberdaya Lahan dan Bangunan

Lahan merupakan salah satu faktor pendukung yang sangat penting dalam mengembangkan suatu usaha produksi karena luas sempitnya lahan akan mempengaruhi besar kecilnya volume usaha produksi yang dapat mempengaruhi besar kecilnya hasil produksi.

Sumberdaya bangunan juga merupakan salah satu faktor pendukung yang sangat penting dalam menjalankan dan mengembangkan suatu usaha karena bangunan merupakan tempat untuk melaksanakan segala aktifitas yang menyangkut kepentingan perusahaan seperti proses produksi serta kegiatan lainnya. Tanpa adanya sumberdaya bangunan, maka perusahaan tidak akan dapat menjalankan kegiatan usahanya secara efektif dan efesien. Adapaun luas ruang produksi sebesar $9 \times 8$ 
meter. Sedangkan luas ruang pemasarannya sebesar 4 x 6 meter.

Luas lahan yang dimiliki oleh usaha pembuatan keripik keladi adalah $20 \times 18$ meter $=360$ meter dengan nilai nominal sebesar Rp 45.000.000 di atas lahan tersebut dibangun sebuah bangunan yang merupakan tempat dimana proses pelaksanaan usaha berlangsung. Luas bangunan tersebut adalah tersebut adalah $9 \times 8$ meter $=$ 72 meter dengan nilai nominal sebesar Rp 75.000.000. Jadi total aset perusahaan untuk sumbedaya lahan dan bangunan yang dimiliki usaha pembuatan keripik keladi adalah sebesar Rp120.000.000

(c) Sumberdaya Finansial

Lancarnya suatu usaha juga sangat tergantung pada keberadaan sumberdaya finansial, sebab sumberdaya finansial sangat berpengaruh pada kestabilan dan perkembangan suatu usaha atau industri. Keberadaan sumberdaya finansial sangat mendukung terhadap pengadaan peralatan dan bahan baku yang dibutuhkan atau digunakan dalam melaksanakan kegiatan produksi.

Sumberdaya finansial merupakan semua harta yang dimiliki oleh usaha pembuatan keripik keladi, baik yang berupa uang tunai maupun dalam bentuk barang berharga yang dapat digunakan untuk mempertahankan kelancaran jalannya suatu usaha pembuatan keripik keladi.

Adapun sumberdaya finansial yang dimiliki usaha pembuatan keripik keladi di Desa Makuang Kecamatan Messawa, aktiva tetap adalah berupa lahan seluas sebesar $20 \times 18$ meter $=360$ meter dengan nilai nominal sebesar Rp 45.000.000dan luas bangunan sebesar9 x 8 meter dengan nilai nominal sebesar Rp 75.000.000. Sedangkan aktiva lancar berupa kas sebesar Rp 6.000.000.

\section{Produksi}

\section{(a) Proses Pengadaan Bahan Baku}

Salah satu aspek yang sangat penting diperhatikan oleh pengusaha pembuatan kripik keladi adalah ketersediaan bahan baku. Mudah tidaknya seorang mendapatakan bahan baku akan mempengaruhi kelancaran proses produksi usahanya.

Bahan baku dalam pembuatan keripik keladi adalah keladi atau sejenis talas. Keladi yang sudah diolah oleh usaha Bapak Ilham, selain didapatkan dari petani keladi juga diperoleh dari hasil kebun Bapak Ilham sehingga menghemat biaya pengeluaran untuk pembelian bahan baku. Rata-rata sebulan yang diperlukan keladi sebagai bahan baku yaitu sebesar $1.200 \mathrm{Kg}$. Sehingga total selama tiga bulan sebesar $3.600 \mathrm{Kg}$

(b) Proses Pembutan Keripik Keladi

Sebelum dibuat menjadi keripik keladi, terlebih dahulu harus disiapkan alat dan bahannya. Adapun alat dan bahan pembuatan keripik keladi adalah sebagai berikut :

1. Alat yang digunakan antara lain :

a. Wajan penggorengan dan peralatnnya untuk menggoreng kripik keladi sebanyak 2 buah. b. Kompor gas digunakan untuk memasak atau menggoreng selama proses produksi kripik keladi, yaitu sebanyak 2 buah

c. Baskom plastik digunakan untuk merendam keladi yang telah dikupas, yaitu sebanyak 3 buah

d. Pisau digunakan untuk memotong-motong bauh keladi dan juga bumbu-bumbu masakan untuk pembuatan kripik keladi, yaitu sebanyak 4 buah

e. Pengaduk digunakan untuk mengaduk kripik agar tidak mudah hangus atau gosong, sehingga memiliki warna dan cita rasa yang menarik, yaitu sebanyak 2 buah

f. Nampan atau tirisan yang terbuat dari bambu digunakan sebagai tempat keripik keladi yang sudah matang untuk ditiriskan, yaitu sebanyak 2 buah

g. Press kemasan digunakan untuk menyegel kemasan plastik kripik keladi agar kripik bertahan lama, yaitu sebanyak 1 buah.

h. Timbangan digunakan untuk menimbang bahan bahan pelengkap (merica, garam, masako, bawang putih dan lain-lain), yaitu 1 buah.

2. Bahan-bahan yang digunakan antara lain :

a. Buah keladi. Buah keladi yang akan dibuat keripik harus dipilih dari jenis keladi yang berkualitas baik dengan ciri-ciri sebagai berikut :memiliki umbi yang besar yaitu 3-4 Kg, berbentuk slinder atau bulat, serat daging umbi berwarna putik kekuning-kuningan. Ratarata keladi yang digunakan selama 1 bulan yaitu 1.200 Kg.

b. Air Bersih. Air bersih digunakan untuk bahan pelarut dan pencuci bahan selama proses pembuatan keripik keladi.

c. Bahan pelengkap, yaitu berupa bumbu-bumbu masakan berupa merica, garam, masako, bawang putih dan lain-lain) untuk memberikan rasa pada kerupuk keladi.

Setelah semua alat dan bahan-bahan siap, maka pembuatan keripik keladi dapat dimulai. Langkahlangkah pembuatan keripik keladi adalah sebagai berikut

1. Kupas keladi lalu dicuci dengan air sampai benarbenar bersih dari kotoran tanah

2. Iris keladi yang sudah bersih membentuk persegi dan tipis-tipis

3. Irisan keladi yang berbentuk persegi kemudian direndam didalam air yang sudah dicampur dengan kapursirih selama 2 jam, kemudian ditiriskan.

4. Keladi yang sudah direndam dengan kapursirih kemudian dijemur dibawah terik matahari sampai benarbenar kering.

5. Keladi yang sudah dikering kemudian dicampur dengan bumbu yang sudah dihaluskan lalu siap digoreng dalam minyak panas sampai matang, angkat dan tiriskan di nampang sampai benar-benar kering dan dingin.

6. Setelah ditiriskan dan sudah dingin kemudian dimasukkan kedalam kemasan dan sebelumnya ditimbang sesuai dengan ukuran dalam kemasan. Dalam 1 kemasan beratnya sebesar 80 Gram

Rata-rata usaha yang dijalankan bapak Ilham bisa memproduksi 633 bungkus/hari atau 50,6 Kg. Dan untuk satu bulan rata-rata yang diproduksi 19.000 
bungkus/bulan atau $1.520 \mathrm{Kg}$ Adapun rincian produksinya dalam 3 bulan terakhir dapat dilihat pada Tabel 1 berikut :

\begin{tabular}{cccc}
\hline No & $\begin{array}{c}\text { Periode } \\
(\text { Bulan })\end{array}$ & $\begin{array}{c}\text { Total } \\
\text { Produksi } \\
(\mathrm{Kg})\end{array}$ & $\begin{array}{c}\text { Rata-Rata Per } \\
\text { Hari }(\mathrm{Kg})\end{array}$ \\
\hline 1 & Februari & 1.520 & 50,6 \\
2 & Maret & 1.440 & 48 \\
3 & April & 1.600 & 53,3 \\
\hline & Jumlah & 4.560 & 151,9 \\
\hline & Rata-rata & 1.520 & 50,6
\end{tabular}

Sumber : Data Primer Setelah Diolah, 2015

Berdasarkan Tabel 1 di atas, terlihat bahwa usaha yang dijalankan Bapak Ilham periode bulan Februari sampai bulan April 2015 dapat memproduksi keripik keladi rata-rata sebesar $50,6 \mathrm{Kg}$ / hari. Dan selama sebulan rata-ratanya sebesar $1.520 \mathrm{Kg}$ / bulan. Produksi keripik keladi tiap bulan bervariasi. Hal ini disebabkan karena untuk bulan Februari produksinya lebih besar disebabkan karena bahan baku yang digunakan juga banyak selain itu permintaan konsumen juga mengalami peningkatan sehingga Bapak Ilham memproduksi keripik keladi lebih banyak. Lain halnya dengan Maret produksinya mengalami penurunan. Hal ini disebabkan karena bahan baku yang digunakan sedikit juga ditunjang dengan sedikitnya konsumen atau minat masyarakat untuk membeli.

Penerimaan usaha Bapak Ilham dalam periode bulan Februari sampai April dapat dilihat pada Tabel 2 sebagai berikut:

Tabel 2. Rata-rata Penerimaan Usaha Pembuatan Kripik Bapak Ilham Selama periode Bulan Februari sampai Maret 2015

\begin{tabular}{lcccc}
\hline $\begin{array}{l}\text { Periode } \\
\text { (Bulan) }\end{array}$ & \multicolumn{2}{c}{ Total Produksi } & \multirow{2}{*}{\begin{tabular}{c} 
Harga \\
Jual/ \\
\cline { 2 - 4 } bungkus
\end{tabular}} & $\begin{array}{c}\text { Nilai } \\
\text { Produksi }\end{array}$ \\
\hline Februari & 19.000 & 1.520 & 3.000 & 57.000 .000 \\
Maret & 18.000 & 1.440 & 3.000 & 54.000 .000 \\
April & 20.000 & 1.600 & 3.000 & 60.000 .000 \\
\hline Total & 57.000 & 4.560 & 9.000 & 171.000 .000 \\
\hline Rata-rata & 19.000 & 1.520 & 3.000 & 57.000 .000 \\
\hline
\end{tabular}

Sumber : Data Primer Setelah Diolah, 2015

Tabel 2 di atas menjelaskan bahwa rata-rata penerimaan usaha yang dijalangkan Bapak Ilham di periode Bulan Februari sampai April 2015 mencapai Rp 57.000.000 Dari total 19.000 bungkus dalam sebulan dengan harga Rp 3.000 per bungkusnya. Adapun puncak produksinya yaitu pada bulan April yaitu sebesar 1.600 $\mathrm{Kg}$. Hal ini disebabkan banyaknya bahan baku yang digunakan untuk memproduksi keripik keladi. Adapun cara memperolehnya yaitu dalam sebungkus sebesar 0,08 $\mathrm{Kg}$ / bungkus. Untuk 20.000 bungkus didapatkan sebesar $1.600 \mathrm{Kg}$.

\section{Analisis Usaha Pembuatan Keripik Keladi}

(a) Biaya Investasi

Investasia adalah merupakan modal yang harus disediakan sebelum melakukan kegiatan produski atau usaha.Biaya investasi biasanya digunakan untuk pengadaan peralatan, proses produksi dan saran penunjang. Adapun rincian biaya investasi untuk usaha pembuatan keripik keladi adalah sebagai berikut :

Tabel 3. Rincian Jumlah Biaya Produksi Usaha Pembuatan Keripik Bapak Ilham Dalam Sebulan

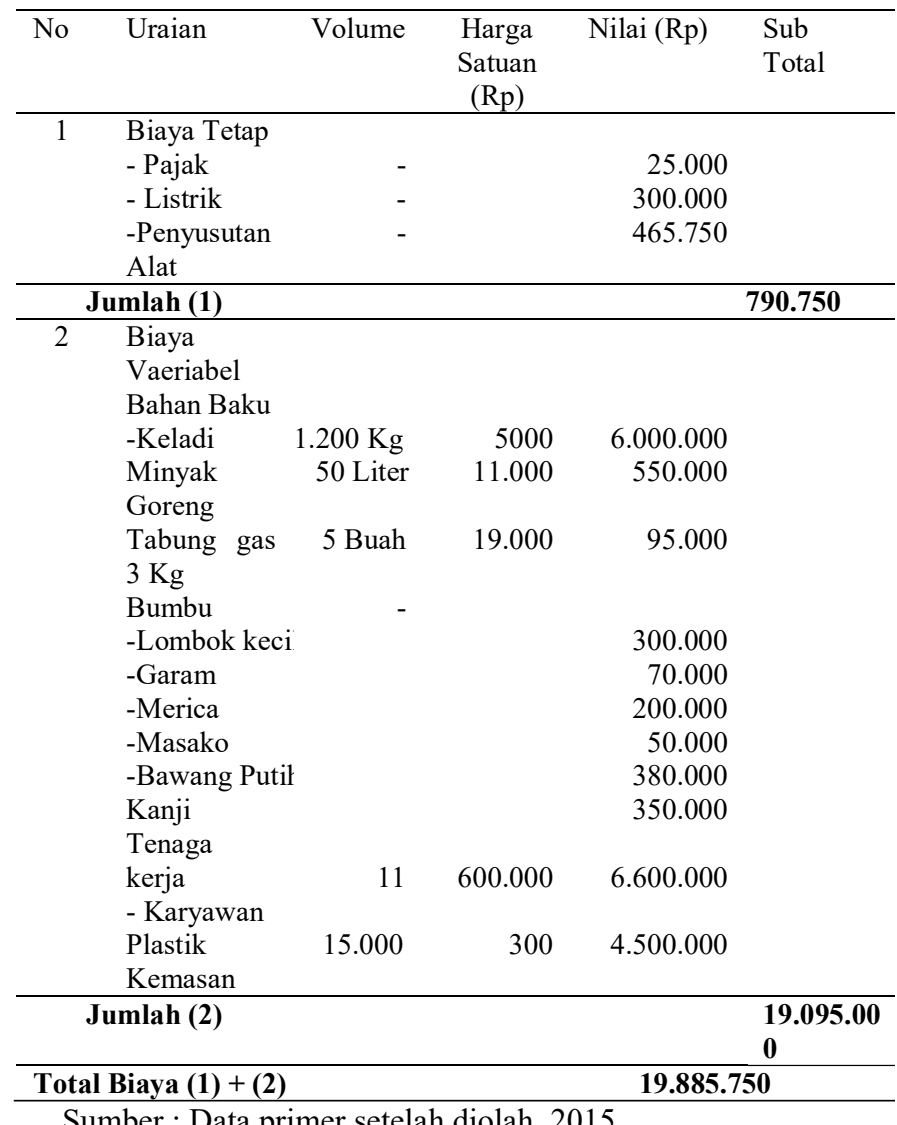

Sumber : Data primer setelah diolah, 2015

Pada Tabel 3 menggambarkan bahwa jumlah total biaya yang dikeluarkan usaha Bapak Ilham dalam proses produksi adalah sebesar Rp 19.885.750 yang terdiri dari biaya tetap sebesar $\mathrm{Rp} 790.750$ dan biaya variabel sebesar Rp 19.095.000

(b) Pendapatan dan Penerimaan

Pendapatan adalah jumlah yang diperoleh dari hasil penjualan produk. Sedangkan penerimaan adalah selisih antara pendapatan dengan total biaya yang produksi. Jika harga keripik keladi dirata-ratakan $\mathrm{Rp}$ 3000/ bungkus dengan jumlah produksi sebanyak 19.000 bungkus atau $1.520 \mathrm{Kg}$ maka pendapatan yang diterima adalah sebagai berikut :

Pendapatan = Jumlah harga per bungkus $\mathrm{x}$ jumlah produksi

$=\operatorname{Rp} 3.000 \times 19.000$ bungkus

$=\operatorname{Rp} 57.000 .000$

Sedangkan penerimaan keripik keladi adalah sebagai berikut :

Penerimaan $=$ Pendapatan - total biaya produksi

$=\operatorname{Rp} 57.000 .000-\operatorname{Rp} 19.885 .750=\operatorname{Rp} 37.114 .250$

(c) Break Event Point (BEP) 
BEP merupakan alat analisis yang digunakan untuk mengetahui batas nilai produksi mencapai titik impas dan dinyatakan layak apabila nilai $\mathrm{BEP}>1$. Adapun hasilnya sebagai berikut :

BEP Produksi : $=$ Total biaya produksi

Harga jual per bungkus

$=\underline{\operatorname{Rp} 19.885 .750}$

$\mathrm{Rp} 3.000$

$=6.628$ bungkus atau $530 \mathrm{Kg}$

$$
\begin{aligned}
\text { BEP Harga }= & \frac{\text { Total biaya produksi }}{\text { Total produksi }} \\
= & \underline{\text { Rp } 19.885 .750} \\
& 19.000 \text { bungkus } \\
= & \text { Rp } 1.047
\end{aligned}
$$

Semua biaya produksi akan tertututpi jika terjual keripik keladi sebanyak 76.628 bungkus atau $530 \mathrm{Kg}$. Maka, usaha keripik keladi di Desa Makuang Kecamatan Messawa Kabupaten Mamasa dinyatakan layak karena produksinya mencapai 19.000 bungkus dengan nilai BEP Produksi $>1$.

Dengan nilai BEP harga sebesar Rp 1.047, maka usaha keripik keladi Desa Makuang Kecamatan Messawa Kabupaten Mamasa dinyatakan layak karena harga penjualan keripik keladi Rp 3.000 / bungkus , dengan nilai BEP harga $>1$

(d) Revenue Cost Ratio ( R/C Ratio)

Analisis R/C Ratio merupakan alat anlisis yang digunakan untuk melihat pendapatan relatif suatu usaha dalam satu tahun terhadap biaya yang dipakai dalam kegiatan tersebut. Berikut perhitungannya :

$\mathrm{R} / \mathrm{C}$ Ratio $=\underline{\text { Total penerimaan }}$

$$
\begin{aligned}
& \text { Total biaya produksi } \\
& =\underline{\operatorname{Rp~37.134.250~}} \\
& \text { Rp 19.885.750 } \\
& =1,87
\end{aligned}
$$

Nilai R/C Ratio usaha pembuatan keripik keladi sebesar 1,87 artinya setiap penambahan biaya sebesar Rp 1 maka akan memperoleh penerimaan sebesar Rp 1,87. Dengan demikian usaha keripik keladi sangat layak untuk dikembangkan karena nila R/C Ratio $>1$.

\section{Kesimpulan}

1. Penerimaan yang diperoleh Bapak Ilham dalam menjalankan usaha pembuatan keripik keladi sebesar Rp 37.114.250 selama tiga bulan

2. $\mathrm{R} / \mathrm{C}$ ratio yang diperoleh dalam melakukan usaha pembuatan keripik keladi yaitu $\mathrm{R} / \mathrm{C}$ ratio sebesar 1,87 berarti usaha tersebut dinyatakan layak, karena setiap penambahan biaya $\mathrm{Rp} 1,-$ maka akan mmperoleh keuntungan sebesar Rp 1,87,-- Dengan demikian usaha pembuatan keripik keladi yang dijalankan memperoleh keuntungan.

\section{Daftar Pustaka}

Assauri, 1993. Manajemen Produksi Dan Operasi. Lembaga Penerbit. Fakultas Ekonomi Universitas Indonesia. Jakarta
Fatah, Z. 1995. Skripsi. Mempelajari Pengaruh Kadar Amilosa Pada Pembuatan Ekstrudat Talas (Colocasia esculenta (L.) Schoot). Fateta IPB. Bogor.

Henry Simanora. 2000. Akuntansi Basis Pengambilan Keputusan Bisnis. Penerbit Salemba empat Jakarta

Ikatan Akuntan Indonesia. 2004. Standar Akuntansi Keuangan. Penerbit Salemba Empat. Jakarta.

Makhruf, 2001.Analisis Pendapatan dan faktor-faktor yang mempengaruhi produksi Usahatani Padi.Institut Pertanian Bogor. Bogor

Masyhuri.1994. Pengembangan Agribisnis dalam Era Globalisasi.Yogyakarta. Fakultas Pertanian UGM

Rosjidi, 1999. Teori Akuntansi. Tujuan Konsep dan Struktur. Edisi Pertama. Lembaga.Penerbit Fakultas Ekonomi Universitas Indonesia. Jakarta

Rosmiatin, E. 1995. Skripsi. Prospek Pengembangan Talas Talas (Colocasia esculenta (L.) Schott) di Kabupaten Bogor Serta Proses Pertumbuhannya Pada Media Casting. Jurusan Biologi FMIFA IPB. Bogor.

Smith-Jay M,Jr Skousen-K, Fred 2001. Akuntansi Keuangan Intermediate.Edisi satu, terjemahan Alfonsus Sirait, penerbit PT. Salemba Empat, Jakarta.

Sitompul S.M dan Guritno B. 1995. Analisis Pertumbuhan Tanaman. Gadjah Mada University Press. Yogyakarta.

Soekartawi, 1995. Analisis Usaha Tani. Penerbit Universitas Indonesia, Jakarta

Wirawati T, B. S. Purwoko, D. Sopandie, I. Hanarida. 2002. Studi Fisiologi Adaptasi Talas terhadap Kondisi Naungan. Seminar Program Pasca Sarjana. Program Pascasarjana, IPB. Bogor. 